\title{
UNA DICHA INFINITA
}

Sobre Andi Nachon. En la música vamos. Buenos Aires: Bajo la Luna, 2019. 448 pp.

Diana Bellessi

Leer el último libro de Andi Nachon fue una dicha infinita, el canto de esta madre hacia una niña que empieza su adolescencia. Pero releer el primero, el libro de Nachon adolescente, me deja sin aliento, y no puedo evitar recordarla en distintos momentos de su vida, la inteligencia de su cabeza y la belleza de su estilo. Desde Siam (1990) hasta En la música vamos o viceversa en la construcción de este libro, esta poeta me hace temblar. Y ahí, en el medio, alzándose del derrumbe neoliberal de los años 2000, 2001, 2002, el punzante y cristalino Plaza real.

Andi Nachon es una poeta de nuestro tiempo, y es mi amiga además. Releerla ha sido para mí una bendición. Viene con nuestros amigos a cuesta: Ursula Le Guin, John Berger y Juana Bignozzi. Pero ahí, en el medio de este tomo de la obra reunida, se alza Plaza real, y ese poema de los chicos pescando en la costanera sur donde pica un dientudo en medio del oleaje de aceite y cosas podridas para mandarlo a la cacerola, nunca lo olvidaré, al son de la cumbia que suena siempre en estos versos. Esos son los poemas que quiero alabar. Tan delicada, tan fina y tan atada a los destinos de la patria Andi Nachon. 
Viene con sus perros y con su criatura esta mujer "...tu cuerpo una galaxia/ hamacada entre mis brazos. No hablás y seguís el ritmo/ vos y yo al unísono". “¿...cuántas mañanas/ anhelé un subte fuera esas pistas donde una puede/ descansar cuerpo y alma en la legión extranjera de otros cuerpos otras/ almas?". Recibí este wasap de Andi al día siguiente de las elecciones primarias en que el neoliberalismo perdió hasta la camiseta: "Qué alegría y alivio. Abrazo Dianita." Por lo que escribe y por lo que es, la amo desde sus catorce años cuando venía con su violín a cuestas a un taller que daba en aquellos tiempos, silenciosa y escribiendo unos versos extraños como los del resto de su vida. Extraños a veces por oscuros y otras por su inmensa claridad lírica que no siempre vi. Y ahora, a cinco días de solo estar leyendo sus poemas me alzo de mi silla y exclamo: jalmita mía, cómo pasó tanto tiempo y yo no te viera pero ahora sí!

Las obras reunidas despliegan una vida y amo la vida de esta poeta. Paso rápido por el olor de aquella papa de Warzsawa (1996) y entro en Taiga (2000): "me hablabas de la lentitud del perezoso en una rama/ su extremada/ levedad entre un intervalo y otro/ -de la quietud al movimiento- yo/ dormía imaginando/ el dibujo trazado por las garras." O la elegancia del verso corto en Goa (2003), en ese bello poema que se llama Animé, o en Digimon: "Y a veces/ te encontrás en el espejo y a pesar/ del mechón erizado/ ves a esa/ mujer que fue tu madre/ atrapada en el reflejo." O en 36 movimientos hacia (2005)" Volvamos a playas/ para despertar con una/ cara en mente bajo soles de Corrientes / frías sobre los pies intrépidos/ la corrida en la espuma y hundimiento/ posterior del cuerpo. 
Año que signás mar y miento/ si me digo puedo/ elegir que siento. Tanta fuerza/ hiciste sobre mi cuerpo". Una rima loca combinada con la palabra esdrújula intrépido hace magia aquí, en esta parte del poema...

¿Quién es esta chica a la que creí conocer durante tantos años?

"Púrpuras profundos: humo sobre el agua, fuego en el cielo", dice en Volumen (2010): "Mesonera yo quiero// cobijo y concentración -sin remordimiento"- o ese poema magnífico que se llama Reina: "demasiado amor puede matarte".

¿Cómo señalar con el dedo lo que quiero decir sin matar la gracia, o como dice el maestro zen Dogen, saltar fuera de los muchos y del uno para encontrar lo inconcebible, ser íntimo o secreto, yo original de Andi Nachon? ¿Cómo se hace además de señalar y señalar versos que no me llevan a ninguna parte? Esa chica se ha convertido en una dama y habla de Mora, su hija y de Wali, su compañero y padre de su hija y antes del hermano mayor -La III guerra mundial- con su espalda cuadrada que a veces le pegaba aunque ella lo amaba y lo seguía por una Patagonia salvaje llena de liebres y de maras... ¿Dónde estás vida mía cuando creo ya alcanzarte? ¿Dónde, dónde que no puedo encontrarte o es así el camino de la poesía, de tu poesía Andi Nachon? Una niña y una dama que se funden por caminos escapistas como Houdini, el gran ilusionista, o sólo esta senda transparente donde todo se ilumina y ahora veo tus cosmonautas azules, tu animé sin igual sobre la reina amada y el hombre del hacha en un solo espacio de oro fundido por el hielo del ártico cuando escribiste en 
Canadá. Es así mi niña hermosa, en medio de todo estás ahí con tu mechón verde o violeta y me decís mamá de vez en cuando o yo te digo así, unidas para siempre Andi querida en los oros cambiantes, hacia el azul, el verde, el gris de la poesía... 